\title{
ADVERSE EFFECT OF TWO-SPOTTED SPIDER MITE (TETRANYCHUS URTICAE KOCH) ON SOYBEAN PROTEIN COMPOSITION
}

\author{
H. Egri BosnyÁKNÉa*, I. KerePesi ${ }^{\mathrm{b}}$ and S. KeSZTHeLYI ${ }^{\mathrm{a}}$

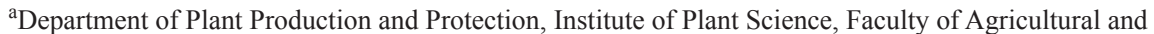 \\ Environmental Science, Kaposvár University, H-7400 Kaposvár, Guba S. utca 40. Hungary \\ ${ }^{\mathrm{b}}$ Department of Genetics and Molecular Biology, Faculty of Sciences, University of Pécs, \\ H-7624 Pécs, Ifjúság útja 6. Hungary
}

(Received: 25 September 2016; accepted: 11 January 2017)

\begin{abstract}
Damage induced on soybean by Tetranychus urticae Koch (Acari: Tetranychidae) is easily recognizable. We were curious to know whether, in addition to this visual and quantitative damage, change occurs also in the nutritional value of the harvested product.

The Weendei analysis showed that as compared to the healthy items, the protein content $(\mathrm{P}=0.048)$ of the miteinjured seeds as well as their composition $(\mathrm{P}=0.048)$ has changed. No significant changes in the raw fat content could be confirmed by the statistical results of the study $(\mathrm{P}=0.643)$. Concerning the contents of raw ash $(\mathrm{P}=0.069)$ and raw fibre $(\mathrm{P}=0.859)$, there were no significant differences.

Three distinct changes in protein structure were confirmed by gel electrophoresis. Substantially less $69 \mathrm{kDa}$ protein was detectable in the infested soybean, whereas no $48 \mathrm{kDa}$ protein was present in the control sample; it only appeared in the infested ones. There was a higher amount of $30 \mathrm{kDa}$ protein in the infested stock. In summary, alteration in the protein structure was caused by T. urticae, and changes were triggered in the protein content of the affected soybean plants. The protein structure-change in damaged soybean items caused further decline in the feed consuming capacity of farm animals.

Keywords: soybean, damage, nutrient content, protein composition, two-spotted spider mite, Tetranychus urticae
\end{abstract}

The sowing area of soybean (Glycine max (L.)) has been increasing in Hungary, as a result of EU efforts (BALIKó et al., 2013; STUMMER et al., 2016). From the angle of nutritional parameters of soybean, the determining factors are protein (38-40\%) and oil contents (18-22\%) (DIRIENZO et al., 2008; Xu et al., 2015). The valuable protein composition can be jeopardized by the piercing-sucking mouthparts pests (VALENCIANO et al., 2004; Biswas, 2013; LiU et al., 2015). In the Carpathian-basin, there is no pre-planned insecticide defence concerning soybean plant protecting technology, because the cost of investment is not commensurate with the expected surplus harvest (BALIKó et al., 2013). However, recent weather anomalies, loosening of the agro-technical discipline, inadequate compliance with crop rotation rules have become notable, that urges reassessment of this view (BALIKó, 2015).

The two-spotted spider mite (Tetranychus urticae Koch), as a dangerous piercingsucking pest, has the ability to reduce the soybean yields and the value of fodders, different kinds of nutrients and food supplements made from soybean. As the effect of mite injury, the

\footnotetext{
* To whom correspondence should be addressed.

Phone: +36304932344; e-mail: b.egrihelga@gmail.com
} 
amount of soluble sugar and the starch-content begin to increase and the phosphorus and nitrogen content of the leaves decrease (HILDEBRAND et al., 1986a).

The change of the ratio of the protein content, which is a result of insect damage, may affect other physiological processes as well, such as susceptibility of the plant to disease, deterioration in stress tolerance, etc. (ATKINSON \& PETER, 2012).

T. urticae damages tender, green parts of plants by their sucking as a result of which amounts of crude nutritional fluids decrease, the plants are stunted, and as a consequence of physiological changes, the leaves will not contain sufficient chlorophyll. At the sites of sucking, light, yellowish stains on the surface of the leaves emerge. On the back side, they create delicate silk tissue under the protection, in which the insects and their eggs can be found (BUDAI, 2002).

T. urticae is a polyphagous species, it causes damage in the arable crops (most importantly corn, soybean, sunflower), in vegetable cultures (melon, cucumber) as well as in fruit plants by sucking the leaves (Boom \& Milstein, 2003).

This is a multivoltine pest with 5-7 sequential generations per year. In the case of favourable weather conditions, a generation develops in 15-28 days during the summer season (Helle \& SABELIS, 1985).

Due to ever hotter and droughty summers, more and more damage is expected, because the dry leaf surface is optimal for rapid growth of the T. urticae. Such leaves become dry prematurely, fall down, the assimilation surface decreases, and the consumption of the stock of chlorophyll subsequently leads to serious metabolism problems (HiLDEBRAND et al., 1986b; SEBESTYÉn \& PÉNZES, 1998).

The increasing level of damage caused by $T$. urticae decreases the chlorophyll content $(55.26 \%)$ and even more dramatically the carotenoid content $(79.3 \%)$ of the leaves. The reaction of the plant against $T$. urticae attack is hypersensitivity, and it generates loss concerning the chlorophyll-content and carotenoids in the leaves (HILDEBRAND et al., 1986a).

It was concluded in an earlier study that in those soybean varieties that are more resistant to damage caused by T. urticae, the initial decline of carotenoid and chlorophyll appeared to be greater than in plants that are more sensitive to it (HILDEBRAND et al., 1986b).

The aim of this study was to understand the effect of T. urticae damage, which disrupts kernel development in soybean; what it entails concerning the composition of soybean forage, particularly its protein and oil content. In this study we measured the starch, raw fat, and protein accumulation, and analysed the change of protein pattern during soybean kernel development.

\section{Materials and methods}

Damaged and intact soybean samples were collected from the Bicsérd arable land of the Forage Crop Research Institute of the Kaposvár University (the GPS coordinates are: N $46^{\circ} 04^{\prime} 08.68^{\prime \prime}, \mathrm{E} 18^{\circ} 05^{\prime} 56.09^{\prime}$ ), in autumn 2015. The collected samples were Johanna variety, which belongs to early maturity group. Before collecting the samples, there was no acaricide treatment on the territory. The soybean pods, which constituted the basis of the samples, were hand-picked off the plants. The samples damaged by the mites were also collected from the plants. The damage was easily discernible due to the mites' sucking. The kernels were removed from the pods, and subsequently the intact and damaged samples were taken to the laboratory, where, following cleaning and sieving, there underwent a Weendei analysis. 
The determination of raw protein, raw fat, ash, and raw fibre contents was carried out in the Physiological and Biochemical Laboratory of the Agricultural and Environmental Sciences Faculty of the Kaposvár University (Kaposvár, Somogy county, Hungary). The raw protein content, the fatty acid composition (Hungarian STANDARD, 1979), the crude fibre content (EC, 2009), and the raw ash content (Hungarian STANDARD, 1992) of the samples were examined on three damaged and intact samples in four replicates (HuNGARIAN STANDARD, 2009).

The protein isolation and SDS-polyacrylamide gel electrophoresis were carried out in the laboratory of the Molecular Biology and Genetics Department at the Faculty of Sciences, University of Pécs. The protein isolation of the samples was implemented on the basis of the protocol worked out by WANG and co-workers (2006). After pulverization, the samples were flash frozen in liquid nitrogen prior to placing them into $2 \mathrm{ml}$ Eppendorf tubes to which $10 \%$ TCA/acetone was added before rigorously shaking them for $30 \mathrm{sec}$. The samples were subsequently centrifuged for $3 \mathrm{~min}$ at $16000 \mathrm{~g}$ in a refrigerated $\left(4^{\circ} \mathrm{C}\right)$ centrifuge before the supernatant was washed. The precipitation was washed with the mixture of $80 \%$ methanol (Scarab) and $0.1 \mathrm{M}$ ammonium acetate (Spectrum 3D). Following another centrifugation $\left(16000 \mathrm{~g}\right.$ at $4{ }^{\circ} \mathrm{C}$ ), the pellet was washed with acetone (Pancreac), prior to drying it at $50{ }^{\circ} \mathrm{C}$ for $10 \mathrm{~min}$. As the next step, the protein was extracted with $0.4-0.8 \mathrm{ml} \mathrm{1:1} \mathrm{ratio} \mathrm{phenol} \mathrm{(pH}$ 8.0; Sigma)/SDS-puffer, depending on the initial cell mass. The protein content of the phenol phase was precipitated overnight by methanol, containing $0.1 \mathrm{M}$ ammonium acetate. On the following day, after 5 min centrifugation $\left(16000 \mathrm{~g}, 4{ }^{\circ} \mathrm{C}\right)$, the protein remained in the form of a white pellet, which was washed with methanol and $80 \%$ acetone. The samples were stored until use at the temperature of $-80{ }^{\circ} \mathrm{C}$ and then they were dissolved in sample puffer. The protein concentration was measured at UV $280 \mathrm{~nm}$ using Nanodrop $2000 \mathrm{UV}-\mathrm{Vis}$ spectrophotometer.

The preparation of SDS-polyacrylamide gels was carried out on the basis of the LAEMMLImethod (1970). For separation, 5\% stacking and 12\% separating gels were used. Gel electrophoresis was implemented by using the Biorad Miniprotean Tetra Cell device. As a test, the samples were exposed to $150 \mathrm{~V}$ voltage (for the purpose of an accelerated electrophoresis) applied for $10 \mathrm{~min}$, while the samples were run at $120 \mathrm{~V}$. Colouring the gels was performed with Coomassie Brilliant Blue dye solution $(0.1 \mathrm{w} / \mathrm{v} \%$ Coomassie Brillant Blue R-250; $40 \mathrm{v} / \mathrm{v} \%$ methanol; $10 \mathrm{v} / \mathrm{v} \%$ glacial acetic acid) for 1.5 hours. The differentiating solution ( $10 \mathrm{v} / \mathrm{v} \%$ acetic acid; $10 \mathrm{v} / \mathrm{v} \%$ methanol) was changed several times. The FluorChemQ - Protein Simple device was used for documentation of the gel images.

For statistical evaluation of the Weendei analysis, a "one factor analysis" of variance was employed using the "R software" package $(\mathrm{P} \leq 0.05)$.

\section{Results and discussion}

The nutritional impairment caused by $T$. urticae has been unequivocally confirmed by the results of Weendei analysis of this study (Fig. 1). The raw protein value $(\mathrm{P}=0.049)$ deviated significantly from the healthy items. The formation of the raw fat showed no significant deviation ( $\mathrm{P}=0.643)$ according to the statistic examination, i.e. the damaged items did not change compared to the healthy ones. Concerning raw fibre content $(\mathrm{P}=0.069)$ and raw ash content $(\mathrm{P}=0.859)$, the statistics did not show significant deviation between the beans damaged by the mite and those which were intact. 


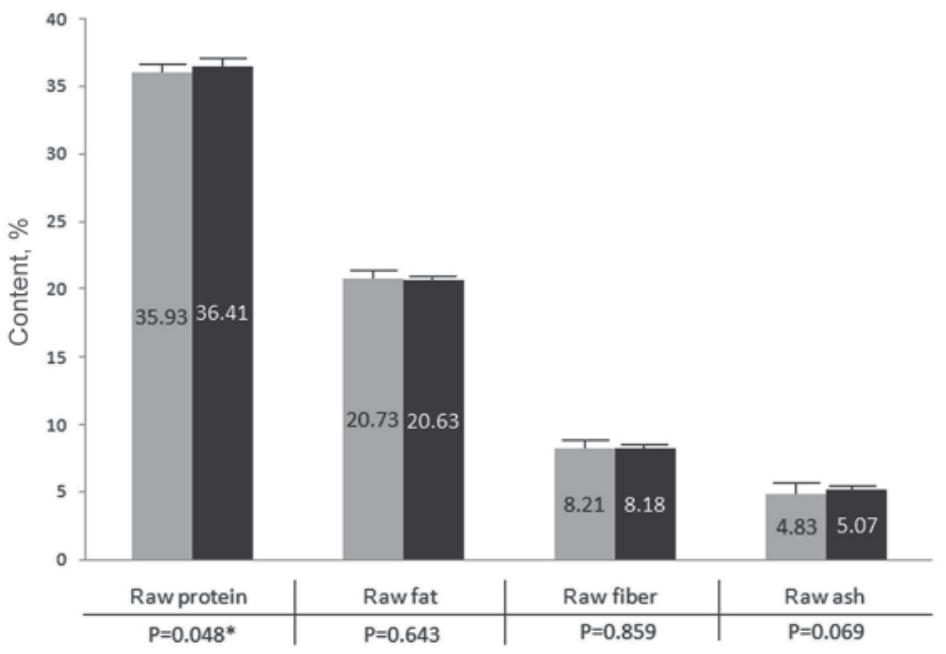

Fig. 1. Nutrient content values $(\% \pm \mathrm{SE})$ of intact and damaged by T. urticae soybean samples ㅍ: intact $(\mathrm{x} \pm \mathrm{SE})$; $\mathbf{\square}$ damaged $(\mathrm{x} \pm \mathrm{SE})$

The findings of the Weendei analysis prompted us to also investigate the protein composition of the damaged and intact items.

The protein composition can be clearly seen in Figure 2. In the gel image, three distinct $\mathrm{kDa}$ proteins can be seen, which changed as a result of damage: there is substantially less 69 $\mathrm{kDa}$ protein in the infested kernels, whereas there is no $48 \mathrm{kDa}$ protein in the control ones, which appeared in the infested ones. There is a considerably higher quantity of $30 \mathrm{kDa}$ protein in the infested samples.

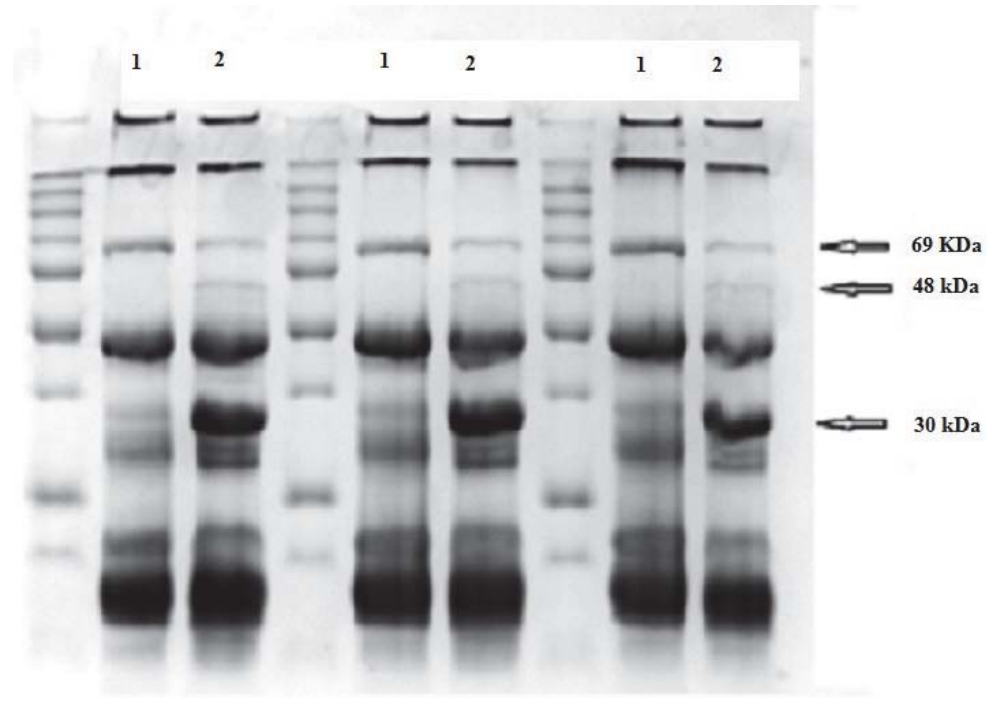

Fig. 2. SDS page protein profiles of intact (1) and damaged by T. urticae (2) soybean samples 
Our findings support the results of other researches (GAYLER \& SYKeS, 1985); namely that the damage caused by mites causes changes in the protein content and composition of crops including soybean, as a result of stress. The nutritional deficiency-diseases may also trigger protein disorders in soybean; the sulphur deficiency for example may reach $40 \%$ of a specific soybean protein: glycinin (GAYLER \& SYKES, 1985). The protein and DNA contents of soybean plants are significantly damaged as a result of oxidative stress (EvANs et al., 1999). The stress status caused by water deficiency is also capable of changing significantly the protein and oil contents of soybean (SIONIT \& KRAMER, 1975). In summary, our investigation proved that this pest causes damage concerning protein content and composition of soybean kernels.

In conclusion, it can be stated that the change in the protein structure of fodder soybean generates an unfortunate situation concerning digestion. Notably, small intestine of piglets, which were fed after ablactation, have rather decreased digestion- and absorption capacity, as it is reflected by the young pigs' diarrhea. In this way, non-essential amino acids, like glutamine, may prevail when different changes regarding proteins occur in forage soybean (Pluske et al., 1997).

Non-appropriate protein consumption has also human related adverse effects. The different soybean based proteins play a role in creating adequate hormonal status and menstruation cycle. This is shown, e.g. by the fact that there is linear relationship between high soybean consumption and low occurrence of breast cancer (CASSIDY et al., 1994).

\section{Conclusions}

The not appropriate soybean protein structure affects flora and fauna through numerous factors, thus whole ecosystems, and subsequently has an impact on humans.

The excessively dry and hot years, which occur more and more frequently, promote proliferation and damage caused by herbivore mites (EASTERBROOK, 1992). On the basis of the results of current investigations, it can be assumed that in the case of future continuation of the present climate extremes and agro technical influences the damage caused by mites will be significant both from quantitative and qualitative points of view (BAKR, 2005). In light of research findings and our test results, the conclusion can be drawn that plant protection interventions against pests may become a reasonable technological element concerning soybean cultivation in the future.

\section{References}

Atkinson, N.J. \& Peter, E. (2012): The interaction of plant biotic and abiotic stresses from genes to the field. J. Exp. Bot., 63, 3523-3543.

BAKR, E.M. (2005): A new software for measuring leaf area, and area damaged by Tetranychus urticae Koch. J. Appl. Entomol., 129, 173-175.

BALiKó, S. (2015): Szójatermesztés korszerüen (Modern soybean cultivation). S-Press $5 \mathrm{Kft}$, Szeged. 111 pages.

Balikó, S., BÁrány, S. \& Galankó, A. (2013): Miért nem termelnek több szóját Magyarországon? (Why not produce more soybeans in Hungary?). Agro Napló, 17, 94-96.

Biswas, G.C. (2013): Insect pests of soybean (Glycine max L.), their nature of damage and succession with the crop stages. J. Asiatic Soc. Bangladesh Sci., 39, 1-8.

Boom, M.E.V.D. \& Milstein, D. (2003): Cyclometalated phosphine-based pincer complexes: mechanistic insight in catalysis, coordination, and bond activation. Chem. Rev., 103, 1759-1792. 
Budai, Cs. (2002): Növényvédelem a zöldséghajtatásban (Plant protection in vegetable growing). Mezőgazda Kiadó, Budapest. 150 pages.

Cassidy, A., Bingham, S. \& Setchell, K.D. (1994): Biological effects of a diet of soybean protein rich in isoflavones on the menstrual cycle of premenopausal women. Am. J. Clin. Nutr., 60, 333-340.

Dirienzo, M.A., Lemke, S.L., Petersen, B.J. \& Smith, K.M. (2008): Effect of substitution of high stearic low linolenic acid soybean oil for hydrogenated soybean oil on fatty acid intake. Lipids, 43, 451-456.

EASTERBRoOK, M.A. (1992): The possibilities for control of two-spotted spider mite Tetranychus urticae on fieldgrown strawberries in the UK by predatory mites. Biocontrol Sci. Techn., 2, 235-245.

EC (2009): Commission Regulation (EC) No 152/2009 of 27 January 2009 laying down the methods of sampling and analysis for the official control of feed (Text with EEA relevance) Annex III/I., Determination of crude fibre, OJEU, L 54/40-42.

Evans, P.J., Gallesi, D., Mathieu, C., Hernandez, M.J., Felipe, M., Halliwell, B. \& Puppo, A. (1999): Oxidative stress occurs during soybean nodule senescence. Planta, 208, 73-79.

GaYler, K.R. \& Sykes, G.E. (1985): Effects of nutritional stress on the storage proteins of soybeans. Plant Physiol., $78,582-585$.

Helle, W. \& SABelis, M.W. (1985): Spider mites their biology, natural enemies and control. Vol. IA, Elsevier, Amsterdam - Oxford - New York - Tokyo. 406 pages

Hildebrand, D.F., Rodriguez, J.G., Brown, G.C., Luu, K.T. \& Volden, C.S. (1986a): Peroxidative responses of leaves in two soybean genotypes injured by two-spotted spider mites (Acari: Tetranychidae). J. Econ. Entomol., 79, 1459-1465.

Hildebrand, D.F., Rodriguez, J.G., Brown, G.C. \& Volden, C.S. (1986b): Two-spotted spider mite (Acari: Tetranychidae) infestations on soybeans: Effect on composition and growth of susceptible and resistant cultivars. J. Econ. Entomol., 79, 915-921.

Hungarian Standard (1979): Takarmányok táplálóértékének megállapítása. Nyers zsirtartalom meghatározása hexános kivonással (Animal feeding stuffs. Determination of nutritive value. Determination of crude fat content. Hexane extract method). MSZ 6830-19:1979 (withdrawn)

Hungarian STANDARD (1992): Takarmányok nyershamutartalmának meghatározása (Animal feeding stuffs. Determination of crude ash). MSZ ISO 5984:1992

Hungarian STANDARD (2009): Takarmányok. A nitrogéntartalom meghatározása és a nyersfehérje-tartalom kiszámitása. 2. rész: Blokkroncsolásos és vízgőz-desztillációs módszer (ISO 5983-2:2009) (Animal feeding stuffs. Determination of nitrogen content and calculation of crude protein content. Part 2: Block digestion and steam distillation method (ISO 5983-2:2009)). MSZ EN ISO 5983-2:2009

LAEMMLI, U.K. (1970): Cleavage of structural proteins during the assembly of the head of bacteriophage T4. Nature, $227,680-685$.

Liu, D., Ning, X., Li, Z., YAng, D., Li, H. \& GAO, L. (2015): Discriminating and elimination of damaged soybean seeds based on image characteristics. J. Stored Prod. Res., 60, 67-74.

Pluske, J.R., Hampson, D.J. \& Williams, I.H. (1997): Factors influencing the structure and function of the small intestine in the weaned pig: a review. Livest. Prod. Sci., 51, 215-236.

Sebestyén, I. \& PÉnZes, B. (1998): Population changes of phytophagous and zoophagous animal species in commercial cucumber cultivation with support system. Növényvédelem, 34(13), 53-61.

Sionit, N. \& Kramer, P.J. (1975): Effect of water stress during different stages of growth of soybean. Agron. J., 69, $274-278$.

Stummer, I., Wanek. Zs., Egri, E., Elek, R., Isépy, A., Keresztessyné Mohr, K., Mándi-Nagy, D. \& Molnár, Zs. (2016): A fontosabb termékpályák piaci folyamatai (The market developments of the most important commodities in 2015). Agrárgazdasági Információk, AKI, Budapest. 82 pages.

Valenciano, J.B., CAsquero, P.A. \& Boto, J.A. (2004): Evaluation of the occurrence of bean plants (Phaseolus vulgaris L.) affected by bean seed fly, Delia platura (Meigen), grown under different sowing techniques and with different forms of pesticide application. Field Crop. Res., 85, 103-109.

Wang, W., Vignani, R., Scali, M. \& Cresti, M. (2006): A universal and rapid protocol for protein extraction from recalcitrant plant tissues for proteomic analysis. Electrophoresis, 27, 278-286.

Xu, X.P., Liu, H., Tian, L., Dong, X.B., Shen, S.H. \& Qu, L.Q. (2015): Integrated and comparative proteomics of high-oil and high-protein soybean seeds. Food Chem., 172, 105-116. 